\title{
PROCESSING AND PROPERTIES OF SINTERED COPPER-IRON AND COPPER-STEEL COMPOSITES
}

\author{
Marek KONIECZNY \\ Kielce University of Technology, Faculty of Mechatronics and Mechanical Engineering, Department of Metals \\ Science and Materials Technologies, Kielce, Poland, EU, mkon@tu.kielce.pl
}

https://doi.org/10.37904/metal.2020.3579

\begin{abstract}
Copper matrix reinforced with iron or carbon steel particulate composites were made by means of the powder metallurgy route. The reinforcement particles were added to copper metal powders with the composition of 15 wt\% Fe and mixed mechanically. Each mixture of the investigated powders was cold compacted at $624 \mathrm{MPa}$. The green compacts were sintered at $900{ }^{\circ} \mathrm{C}$ in dissociated ammonia atmosphere. Identification of the structure was performed on the basis of iron-copper phase diagram. Results of X-ray microprobe analysis allowed to find that the reinforcement particles were connected with copper matrix by solid solutions. Also the concentration of iron in copper across the iron (or steel)-copper matrix boundary was investigated. Measurements showed that the highest hardness of $41 \mathrm{HB}$ could be achieved for $\mathrm{Cu}$-steel composites because particles contained cementite. The same composites also had higher electrical conductivity $(27 \mathrm{MS} / \mathrm{m}$ that was about $48 \%$ of electrical conductivity of sintered copper) because their copper matrix contained lower concentration of iron atoms. Tribological tests showed that the wear mass loss of the copper-steel composites was approximately 2 times smaller than for the copper-iron composites and about 2.3 times smaller than for sintered copper.
\end{abstract}

Keywords: Copper, iron, carbon steel, sintered composite, properties

\section{INTRODUCTION}

Both copper and copper alloys have a wide range of properties that account for their extensive use as engineering materials. A pure copper has a very good electrical and thermal conductivity but on the other hand has also a very low abrasion resistance. The copper-based alloys generally have high level of hardness and wear resistance, but their electrical conductivity is low in comparison with copper. For example, silicon bronze, tin bronze, and manganese bronze have an electrical conductivity lower than $10 \mathrm{MS} / \mathrm{m}$ while pure copper has even 58.6 MS/m [1]. Therefore, it appears that composites containing high purity copper and hard particles or layers could meet the opposed requirements: high electrical conductivity and high abrasion resistance. This second phase could be composed of other metals [2-4], intermetallics [5-7] or ceramics [8-17]. Metalintermetallic composites offer an attractive combination of the component properties. The process of synthesis between elemental powders or foils has been widely used to produce intermetallic and ceramic powders and two-phase composites [5-7]. Unfortunately, during the synthesis process between metals atoms can migrate to copper significantly lower the conductivity. On the other hand, ceramic particles in composites are not conjoined with metal matrix and can be easily removed. The conductivity of a material produced by powder metallurgy (PM) is normally affected by the material porosity, which is typical for PM parts $[3,18]$. Besides porosity, the interface between different phases in the microstructure, as well as powder initial shape and surface chemical characteristics can also affect the electrical and thermal conductivity [19]. In heterogeneous materials, the thermal and electrical conductivity is also affected by the phases distribution and chemical composition, especially when there is the formation of intermetallics, which can decrease the conductivity [3]. Therefore, using particles of iron or iron-carbon alloys that do not form any intermetallics with copper seems 
to be a good idea. The purpose of this study was to recognize the effect of sintering process on the microstructure, hardness and electrical conductivity of copper-matrix composites with iron-based particles as well as investigate their wear behavior.

\section{EXPERIMENTAL PROCEDURE}

Materials used in this experiment were copper (99.9 at\% Cu), iron (99.84 at\% $\mathrm{Fe}$ ) and plain-carbon steel (containing 98.56 at\% $\mathrm{Fe}, 0.79$ at\% C, 0.24 at\% Mn, 0.23 at\% Si, 0.14 at\% $\mathrm{Cr}, 0.02$ at\% S and 0.02 at\% P) powders. The average grain size of all used powders was in the range from 20 to $100 \mu \mathrm{m}$. The cylindrical specimens of $20 \mathrm{~mm}$ in diameter and $10 \mathrm{~mm}$ high from pure copper or mechanically mingled mixtures containing additionally $15 \mathrm{wt} \%$ of iron or carbon steel were subjected to single-track pressing on a hydraulic press at a compaction pressure of $624 \mathrm{MPa}$. The green compacts were sintered at $900{ }^{\circ} \mathrm{C}$ for $1 \mathrm{~h}$ in a sillit tubular furnace in dissociated ammonia atmosphere and then cooled in a cooler mounted in the furnace. The microstructure analyseis on the metallographic specimens were performed using scanning electron microscope JEOL JMS 500. The chemical composition of the investigated regions was determined by an electron microprobe analysis using ISIS 300 Oxford Instruments. Identification of the phases was performed on the basis of iron-copper phase diagram. The hardness of the composites was measured with a steel ball of $5 \mathrm{~mm}$ in diameter at a load of $2453 \mathrm{~N}$ using the Brinell method in accordance with the EN ISO 6506-1:2014 standard. The electrical conductivity tests were performed using the GE Phasec 3D device employing the eddy current method. The density of sintered materials was determined by weighing the specimens in air and water using WPA120 hydrostatic scales in line with the EN ISO 2738:2001 standard. The tribological tests were conducted using device with a roll on block configuration. The roll of $\phi 35 \mathrm{~mm} \times 9 \mathrm{~mm}$ was made of hardened $100 \mathrm{Cr} 6$ steel with a hardness of $62 \mathrm{HRC}$. The blocks with a dimension of $6 \mathrm{~mm} \times 8 \mathrm{~mm} \times 15 \mathrm{~mm}$ were made of sintered materials. The test was performed with a rotational speed of $130 \mathrm{rpm}$ with a load of $5 \mathrm{~N}$. The loss of weight was measured with accuracy of $0.0001 \mathrm{~g}$ every 10 minutes during the test which lasted $1 \mathrm{~h}$. The total path of friction was $864 \mathrm{~m}$.

\section{RESULTS AND DISCUSSION}

\subsection{Microstructural investigations}

At the beginning of the investigations the microstructure of fabricated composites was studied. First the analysis was performed by an optical microscope (Figure 1).


Figure 1 Microstructure of copper-iron (a) and copper-steel (b) composites 
The introduction of powdered iron (or steel) particles caused a distinct change in microstructure of obtained composites. Both types of particles of various sizes were evenly distributed in a copper matrix. Only in certain areas of composites, the particles were bonded into agglomerates. Introduced particles have not dissolved in the matrix during the sintering process, but were connected with copper matrix by solid solution that could be seen around them. Then the microstructure of copermatrix composites was studied by a scanning electron microscope (SEM) equipped with a system for microprobe analysis. The main aims of these examinations were identification of the chemical composition of synthesized phases and determination of the iron concentration profile across the interface between copper and reinforcement particles. A study of the microstructures was based on the Fe$\mathrm{Cu}$ binary phase diagram presented in Figure 2.

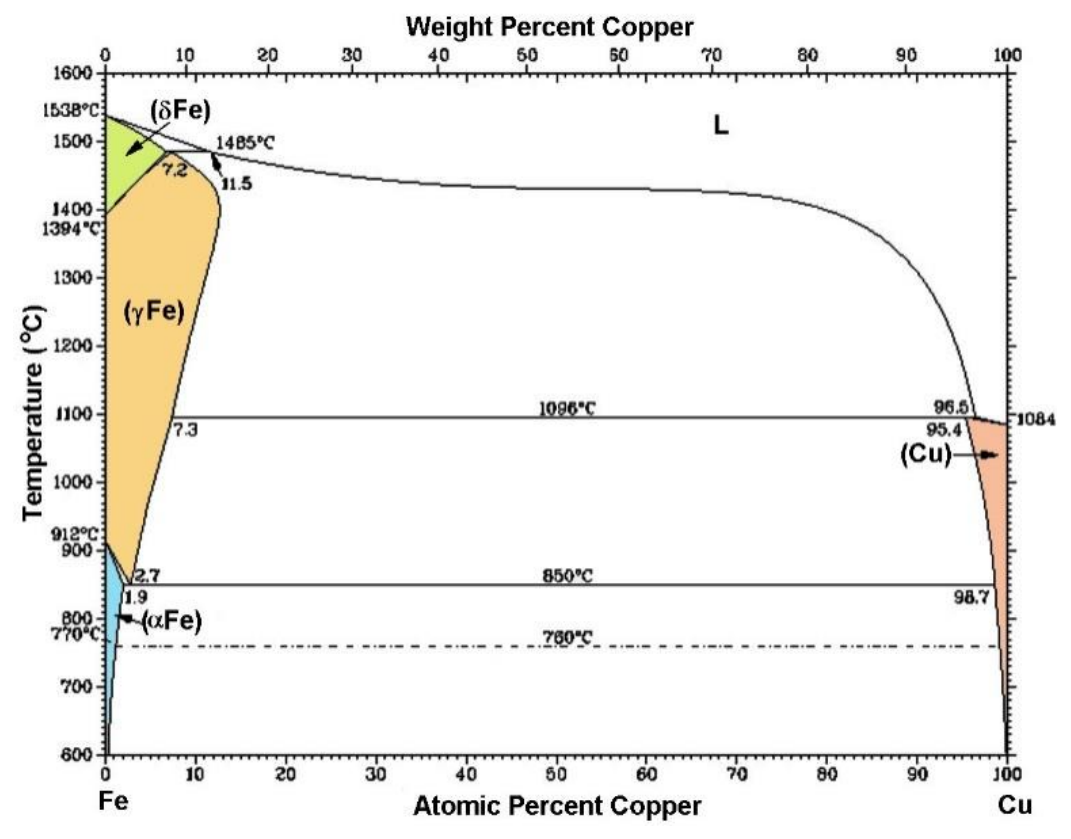

Figure $2 \mathrm{Fe}-\mathrm{Cu}$ binary phase diagram [20]

The elemental analysis performed by the X-ray spectroscope was made for three different regions of the diffusion zone indicated by dots in Figure 3.

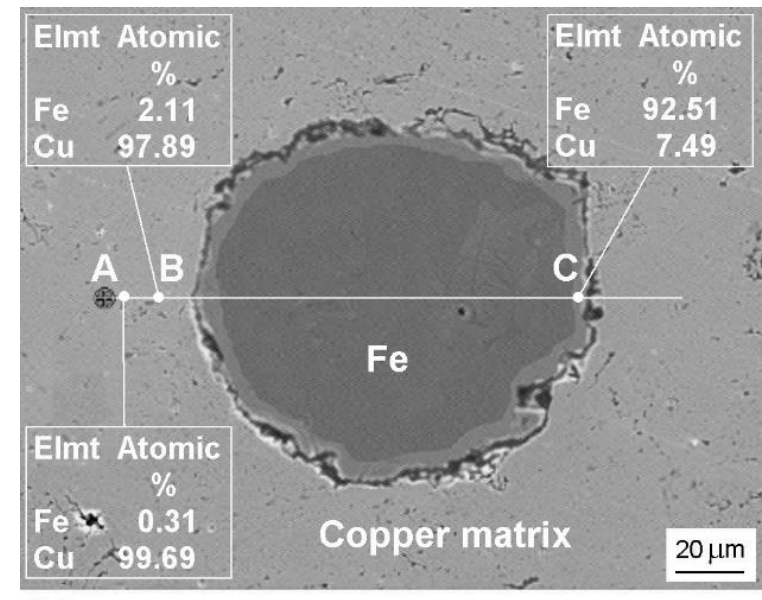

(a)

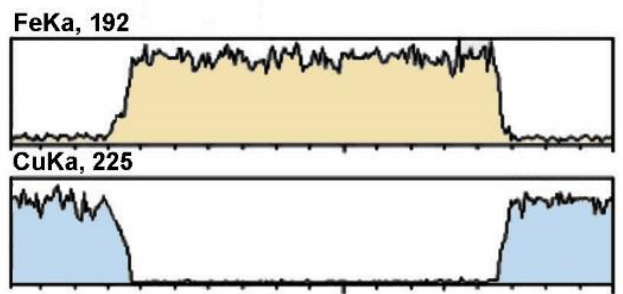

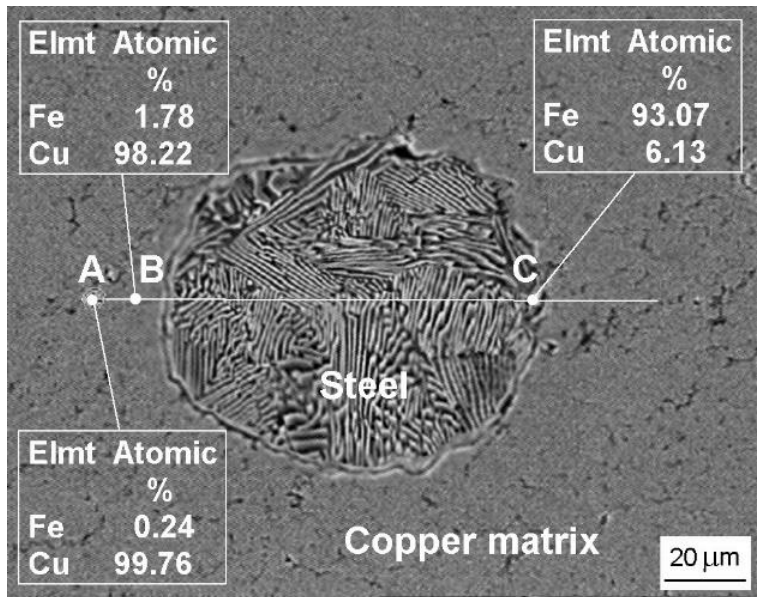

(b)

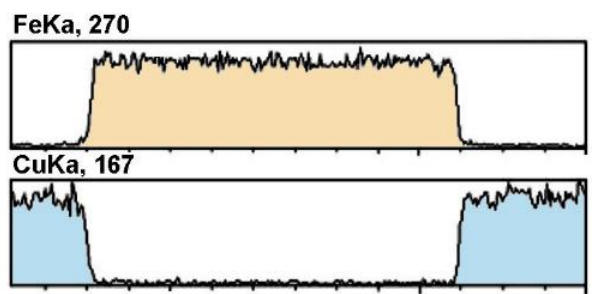

Figure 3 Places of elemental analysis of the diffusion zone between iron (a) and steel (b) particles and copper together with $\mathrm{Fe}$ and $\mathrm{Cu}$ concentration profiles across particles and matrix 
An exemplary X-ray diffraction spectrum for diffusion zone is given in Figure 4. The Fe and Cu content, 92.51 and 7.49 at. \%, respectively, suggests (accordingly to the Fe-Cu binary phase diagram) a mixture of two solid solutions: $(\alpha \mathrm{Fe})$ and $(\mathrm{Cu})$.



Figure $4 \mathrm{X}$-ray spectrum for region $\mathrm{C}$ depicted in Figure $\mathbf{3 a}$

It is very important for the high electrical conductivity to maintain a low concentration of iron in the coppermatrix of composites. The plot of the concentration of $\mathrm{Fe}$ and $\mathrm{Cu}$ across copper-particles border obtained by $\mathrm{X}$-ray diffraction is presented in Figure 3. The results of the Fe concentration measurements are listed in Table 1.

Table 1 Iron content in copper matrix at the copper-particle boundaries

\begin{tabular}{|c|c|c|}
\hline \multirow{2}{*}{$\begin{array}{c}\text { Distance from boundary } \\
(\mu \mathrm{m})\end{array}$} & \multicolumn{2}{|c|}{ Iron concentration in copper matrix (at. \%) } \\
\cline { 2 - 3 } & Copper-iron composite & Copper-steel composite \\
\hline 10 & 2.11 & 1.78 \\
\hline 20 & 0.31 & 0.24 \\
\hline 30 & 0.12 & 0.08 \\
\hline
\end{tabular}

The concentration profiles show that the penetration of Fe atoms across the copper-particle boundaries was limited and fell quickly with the distance from the interphase boundary. Interesting is fact, that for carbon steel particles the diffusion of iron atoms to copper matrix came to a smaller depth. Perhaps carbon atoms in steel slowed down this process.

\subsection{Density, hardness and electrical conductivity measurements}

The results of density, hardness and electrical conductivity measurements are presented in Table 2. For comparison there were also performed measurements for sintered copper.

Table 2 Results of performed measurements for sintered copper and copper-particles composites

\begin{tabular}{|c|c|c|c|}
\hline Material & $\begin{array}{c}\text { Density } \\
\left(\mathrm{g} / \mathrm{cm}^{3}\right)\end{array}$ & $\begin{array}{c}\text { Hardness } \\
\text { HB }\end{array}$ & $\begin{array}{c}\text { Electrical conductivity } \\
(\mathrm{MS} / \mathrm{m})\end{array}$ \\
\hline Sintered pure copper & $8.18 \pm 0.01$ & $34 \pm 1.5$ & $56 \pm 0.6$ \\
\hline Copper-iron composite & $8.03 \pm 0.02$ & $42 \pm 1.3$ & $25 \pm 0.5$ \\
\hline Copper-steel composite & $7.95 \pm 0.02$ & $49 \pm 0.6$ & $27 \pm 0.4$ \\
\hline
\end{tabular}


The obtained results of measurements showed that the introduction of iron and steel particles decreased density of materials, which oscillated around $8 \mathrm{~g} / \mathrm{cm}^{3}$ and was about $92 \%$ of theoretical. Similar results were also received by other researchers [3,4]. The examinations showed that, the introduction of iron and especially steel particles into the copper matrix increased the hardness of the materials, however, these changes were slight (24 and $44 \%$ for iron and steel particles, respectively, in comparison to sintered copper). The particles of steel contained $0.79 \%$ carbon in the form of cementite (perlite is shown in Figure $\mathbf{3 b}$ ) and therefore were much harder than iron particles (200 and $54 \mathrm{HB}$ for perlite and iron, respectively). Even distribution of particles in the copper matrix (Figure 1) was the main reason for the increasing of hardness. Similar results were also reported by other researchers [2,13-17]. The examination showed that the introduction of iron-based particles into copper matrix caused considerable decrease in electrical conductivity. This phenomenon was due to the fact that even a small amount of alloy additives in copper causes a reduction of their electrical conductivity [1]. Higher electrical conductivity was obtained for copper-steel composites which amounted approximately 27 $\mathrm{MS} / \mathrm{m}$ (48\% conductivity of sintered copper). Electrical conductivity of copper-iron composites was even smaller (44.6\% of sintered copper). The difference was caused by a deeper diffusion of iron into the copper matrix for copper-iron composites, which was shown in Table 1. These results are consistent with those reported by Ugarteche Velasques [3].

\subsection{Wear characterization}

Weight loss of sintered copper and composites during tribological test is shown in Figure $\mathbf{5}$.



Figure 5 Weight loss of investigated materials during tribological tests lasting $1 \mathrm{~h}$

Tribological tests showed that the presence of steel particles in cooper matrix significantly increased abrasion resistance. The wear mass loss of the copper-steel composites was approximately 2 times smaller than for the copper-iron composites and about 2.3 times smaller than for sintered copper. The steel particles consisting of perlite are hard and they have much higher abrasion resistance in comparison with copper and iron. Important is also fact that they are distributed evenly in the copper matrix (Figure 1b). Similar observations were also reported by other researchers $[2,9,16]$.

\section{CONCLUSION}

Copper-iron and copper-carbon steel particulate composites can be easily made by means of the powder metallurgy route. Results of X-ray microprobe analysis show that the reinforcement particles are connected with copper matrix by solid solutions. The concentration of iron in copper, measured across the copper-particle boundaries, strongly decreases with increasing distance from the interphase boundary. Carbon atoms in steel slow down diffusion of iron to copper matrix. Measurements show that the highest hardness of $41 \mathrm{HB}$ can be 
achieved for Cu-steel composites because particles contain cementite. The same composites also have higher electrical conductivity ( $27 \mathrm{MS} / \mathrm{m}$ that is about $48 \%$ of electrical conductivity of sintered copper) because their copper matrix contains lower concentration of iron atoms. Tribological tests show that the wear mass loss of the copper-steel composites is approximately 2 times smaller than for the copper-iron composites and about 2.3 times smaller than for sintered copper.

\section{REFERENCES}

[1] DAVIS, J.R. Copper and Copper Alloys. Materials Park Ohio: ASM International, 2001.

[2] KATO, H., TAKAMA, M., YWAI, Y., WASHIDA, K., SASAKI, Y. Wear and mechanical properties of sintered copper-tin composites containing graphite or molybdenum disulfide. Wear. 2003, vol. 255, pp. 573-578.

[3] UGARTECHE VELASQUES, C. et al. Effect of microstructure on the thermal properties of sintered iron-copper composites. Materials Research. 2015, vol. 18, pp. 1176-1182.

[4] ZHANG, Z., SANDSTROM, R., WANG, L. Modelling of swelling of Fe-Cu compacts sintered at temperatures above the copper melting point. Journal of Materials Processing Technology. 2004, vol. 152, pp. 131-135.

[5] DZIADOŃ, A., KONIECZNY, M., GAJEWSKI, M., IWAN, M., RZĄCZYŃSKA, Z. Microstructure evolution at the $\mathrm{Cu}$-Ti interface during high temperature synthesis of copper-intermetallic phases layered composite. Archives of Metallurgy and Materials. 2009, vol. 54, pp. 455-466.

[6] KONIECZNY, M., DZIADOŃ, A. Mechanical behaviour of multilayer metal-intermetallic laminate composite synthesised by reactive sintering of $\mathrm{Cu} / \mathrm{Ti}$ foils. Archives of Metallurgy and Materials. 2007, vol. 52, pp. 555-562.

[7] KONIECZNY, M. Deformation mechanisms in copper-intermetallic layered composite at elevated temperature. Kovové Materiály-Metallic Materials. 2007, vol. 45, pp. 313-317.

[8] KARGUL, M., BOROWIECKA-JAMROZEK, J., KONIECZNY, M. Fabrication and characteristics of sintered copper-silica composites. IOP Conference Series: Materials Science and Engineering, 2018, 461, 012005.

[9] RAJKUMAR, K., ARAVINDAN, S. Tribological performance of microwave sintered copper-TiC-graphite hybrid composites. Tribology International. 2011, vol. 44, pp. 347-358.

[10] UPADHYAYA, A., UPADHYAYA, G.S. Sintering of copper-alumina composites through blending and mechanical alloying powder metallurgy routes. Materials \& Design. 1995, vol. 16, pp. 41-45.

[11] DASH, K., RAY, B.C., CHAIRA, D. Synthesis and characterization of copper-alumina metal matrix composite by conventional and spark plasma sintering. Journal of Alloys and Compounds. 2012, vol. 516, pp. 78-84.

[12] MOUSTAFA, S.F., ABDEL-HAMID, Z., ABD-ELHAY, A.M. Copper matrix $\mathrm{SiC}$ and $\mathrm{Al}_{2} \mathrm{O}_{3}$ particulate composites by powder metallurgy technique. Materials Letters. 2002, vol. 53, pp. 244-249.

[13] CELEBI EFE, G., YENER, T., ALTINSOY, I., IPEK, M., ZEYTIN, S., BINDAL, C. The effect of sintering temperature on some properties of $\mathrm{Cu}-\mathrm{SiC}$ composite. Journal of Alloys and Composites. 2011, vol. 509, pp. 6036-6042

[14] LARA-GUEVARA, A. et al. Synthesis of copper-alumina composites by mechanical milling: an analysis. Materials and Manufacturing Processes. 2013, vol. 28, pp. 157-162.

[15] SORKHE, Y.A., AGHAJANI, H., TABRIZI, A.T. Mechanical alloying and sintering of nanostructured $\mathrm{TiO}_{2}$ reinforced copper composite and its characterization. Materials \& Design. 2014, vol. 58, pp. 168-174.

[16] PENG, L. Fabrication and properties of $\mathrm{Ti}_{3} \mathrm{AlC}_{2}$ particulates reinforced copper composites. Scripta Materialia. 2007, vol. 56, pp. 729-732.

[17] NGAI, T.L., ZHENG, W., Li, Y. Effect of sintering temperature on the preparation of $\mathrm{Cu}_{-} \mathrm{Ti}_{3} \mathrm{SiC}_{2}$ metal matrix composite. Progress in Natural Science: Materials International. 2013, vol. 23, pp. 70-76.

[18] VINCENT, C., SILVAIN, J.F., HEINTZ, J.M., CHANDRA, N. Effect of porosity on the thermal conductivity of copper processed by powder metallurgy. Journal of Physics and Chemistry of Solids. 2012, vol. 73, pp. 499-504.

[19] LEONG, C.C., LU, L., FUH, J.Y., WONG, Y.S. In-situ formation of copper matrix composites by laser sintering. Materials Science and Engineering A. 2002, vol. 338, pp. 81-88.

[20] OKAMOTO, H., SCHLESINGER, E., MUELLER, M., eds. ASM Handbook Volume 3 Alloy Phase Diagrams. Materials Park Ohio: ASM International, 2016. 